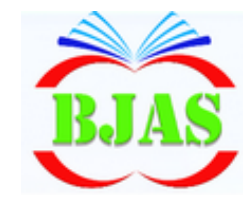

Available online at http://bajas.edu.iq https://doi.org/10.37077/25200860.2019.258 College of Agriculture, University of Basrah

ISSN $1814-5868$
Basrah Journal of Agricultural Sciences

\title{
Bacterial Fish Diseases in some Semi-close Aquaculture Systems in Basrah Province, Iraq
}

\author{
Abdul Amer R. Jassim ${ }^{1 *}$, Diana B. Abdulhameed ${ }^{2}$ and Nadia A. Al Shammari ${ }^{1}$ \\ ${ }^{1}$ Department of Biological Development of Shatt Al-Arab and North Arabian Gulf, \\ Marine Science Centre, University of Basrah, Iraq \\ ${ }^{2}$ College of Pharmacy, University of Misan, Iraq \\ *Corresponding author e-mail: abdulamer.jassim@yahoo.com \\ Received 19 September 2019; Accepted 18 November 2019; Available online 22 November 2019
}

\begin{abstract}
The object of this study was to detect the bacterial species that founded in infected common carps Cyprinus carpio in semi-closed systems in two districts of Basrah province. Bacterial gill disease, skin ulcer disease and intestine inflammatory disease were recorded. In the present study, Aeromonas sobria (38.46) was the predominant species, followed by Citrobacter freundii (29.23), Vibrio cholerae (21.53) and Serratia fonticola (10.76\%). Identification of the isolates was carried out depending on the morphology of colony, specific media and identification using VITEK 2 system (Biomerieux- USA). Five antibiotic discs were used for antibiotic sensitivity test by the disk diffusion method. A. sobria was sensitive to Nitrofurantion, $V$. cholerae was sensitive to Ampicillin, $C$. freundii was resistance for all antibiotics while $S$. fonticola was sensitive to Gentamicin. This study represented the first investigation in Iraq on bacterial isolates from semi- closed system.
\end{abstract}

Keywords: Bacteria, Fish, Diseases, Aquaculture.

\section{Introduction}

experience. As aquaculture continues to become more intensive and expands into new frontiers, fish health problems are likely to become more significant (Buller, 2004). Bacterial gill disease is one of the most influent problem which faces aquaculture in the world. For example, in freshwater aquaculture, bacterial septicaemia is considered to be one of the most important diseases in history of Chinese aquaculture (Qi, 2002). The present study was designed to detect bacterial fish diseases in semi-enclosed
In recent years, closed and semi-enclosed aquaculture systems had been used in Iraq due to water shortage. There are many examples of recirculation systems operating without any disease problems at all (Bregnballe, 2015). This type of culture requires good knowledge and high training and it's not available in all projects that were established in Basrah Province. So, most projects face different problems and the farmer preferred the semienclosed aquaculture system. This means that the health problems will certainly be present due to bad management and lack of 
(India), Nitrofurantion 300, Gentamicin 10, Tetracycline 30, Erythromycin 15 and Ampicillin 10 as shown in tables $(3,4,5$ and 6).

\section{Results}

\section{Signs of diseases}

The infected fishes swimmed slowly and tried to make bubbles near the water surface and this is the normal reaction of the fish when the level of oxygen is low in water, but in this case, the problem is related to the decrease of the efficiency of breathing due to the crash of gill plates. It was noted that infected fish head was slightly above the horizontal line of the body during swimming. The fishes in the acute stages lose the reaction to any stimuli and swam so quietly that they can be held by hand. Prevalence of infection in both locations was very high (more than 90\%) and there are mortality 1030 fish per day.

Clinical identification: In this study, three type of bacterial diseases were identified. Bacterial gill disease (B.G.D.) and skin ulcer disease were recorded in both locations while intestine inflammatory disease (I.I.D.) was recorded in Abu Alkhaseeb district only (table 1). Identified bacterial species of B.G.D. were Vibrio cholerae Pacini, 1854 and Aeromonas sobria Popoff \& Veron, 1981 in Abu Al-Khaseeb district while Citobacter freundii (Braak, 1928) Werkman \& Gillen, 1932 and V. cholerae in Shatt Al-Arab district. For the skin ulcer disease, the pathogen was A. sobria only in both districts. Pathogens of intestine inflammatory disease were Serratia fonticola Gavini, Ferragut, Izard, Trinel, Leclerc, Lefebvre \& Mossel, 1979 and C. freundii (Table 1) in Abu Al-Khaseeb district only.

In the present study, A. sobria (38.46\%) was the predominant species, followed by $C$. freundii $(29.23 \%)$, V. cholerae $(21.53 \%)$ and S. fonticola (10.76\%) (Table 2). These aquaculture system in Basrah province and identify their pathogens.

\section{Materials \& Methods}

Common carps were collected during the period from February to March 2018 from two infected fish farms (semi-closed system) in two locations of Basrah province, Iraq (Shatt Al-Arab and Abu Alkhaseeb districts).

Fish samples (100-250 g) were transported to the laboratory in chill condition. The samples were morphologically inspected at first and after that, gills and other organs were cut and examined under a dissecting microscope (Optika SZM-1) to detect signs of diseases.

One gram of infected tissue was taken from the gills and the intestine and homogenized in nine $\mathrm{ml}$ of sterile normal saline solution using a sterilized glass homogenizer (Brand- Germany). One millilitre of solutions were serially diluted $\left(10^{-1}\right.$ to $\left.10^{-7}\right)$. An amount of $0.1 \mathrm{ml}$ of the serial dilutions were inoculated onto nutrient agar (N.A.), trypticase soy agar (TSIA) and thiosulfate citrate bile sucrose salt agar (TCBS) from Hi media (India). The plates were incubated at $37^{\circ} \mathrm{C}$ for $24 \mathrm{~h}$ (N.A. and TSIA) and for $48 \mathrm{~h}$ (TCBS). One growth of colonies was transported to new media at the same temperature and time above. Isolated bacteria were morphologically identified and distinguished to Gram positive and negative. Pure growths cultured on N.A. at $37 \mathrm{C}^{\circ}$ for 24 $\mathrm{h}$ after that were picked to bacterial identification using VITEK 2 system (Biomerieux- USA).

Five antibiotic discs were used for antibiotic sensitivity test, performed by the disk diffusion method according to CLSI (2116) guidelines using antibiotic discs on Mueller-Hinton agar (MH) of $\mathrm{Hi}$ media 
Jassim et al ./ Basrah J. Agric. Sci., 32(Spec. Issue 2): 75-84, 2019

4), V. cholerae was sensitive to Ampicillin (Table 5), C. freundii was resistant for all antibiotics (Table 6) while $S$. fonticola was sensitive to gentamicin (Table 6). species were identified by VITEK 2 system and the probability was high (Table 3 ). Antibiotic sensitivity test showed that $A$. sobria was sensitive to Nitrofurantion (Table

Table (1): Diseases and bacterial pathogens of the two districts.

\begin{tabular}{lll}
\hline \multicolumn{1}{c}{ Locations } & Diseases & Bacterial pathogens \\
\hline \multirow{3}{*}{ Abu Al-Khaseeb } & B.G.D. & V. cholerae, A. sobria \\
\cline { 2 - 3 } & Skin ulcer & A. sobria \\
\cline { 2 - 3 } & Intestine inflammatory disease & S. fonticola, C. freundii \\
\hline \multirow{3}{*}{ Shatt Al-Arab } & B.G.D. & C. freundii, V. cholera \\
\cline { 2 - 3 } & Skin ulcer & A. sobria \\
\cline { 2 - 3 } & Intestine inflammatory disease & - \\
\hline
\end{tabular}

Table (2): Number and percentage of isolated bacteria.

\begin{tabular}{lcc}
\hline \multicolumn{1}{c}{ Bacterial Species } & No. & Isolated bacteria (\%) \\
\hline Aeromonas sobria & 25 & 38.46 \\
\hline Citrobacter freundii & 19 & 29.23 \\
\hline Vibrio cholera & 14 & 21.53 \\
\hline Serratia fonticola & 7 & 10.76 \\
\hline
\end{tabular}

Table (3): Number of bacterial isolates diagnosed and the probability of the diagnosis by using VITEK 2 system.

Bacterial species $\quad$ No. Probability Time per h Unidentified

(\%) bacteria

\begin{tabular}{lccc}
\hline Aeromonas sobria & 25 & 95 & 5 \\
\hline Citrobacter freundii & 19 & 97 & 5.75 \\
\hline Vibrio cholera & 14 & 94 & 5 \\
\hline Serratia fonticola & 7 & 95 & 4 \\
\hline
\end{tabular}

Table (4): The value of resistance of Aeromonas sobria to antimicrobial agents.

\begin{tabular}{lccc}
\hline Type of antibiotics & $\begin{array}{c}\text { Concentration } \\
\left(\mathrm{mcg}_{\mathrm{g}} \mathrm{g}^{-1}\right)\end{array}$ & $\begin{array}{c}\text { Type } \\
\text { of resistance }\end{array}$ & $\begin{array}{c}\text { Diameter of } \\
\text { inhibition zone }(\mathrm{mm})\end{array}$ \\
\hline Nitrofurantoin & 300 & $\mathrm{~S}$ & 25 \\
\hline Gentamicin & 10 & $\mathrm{R}$ & - \\
\hline Tetracycline & 30 & $\mathrm{R}$ & 7 \\
\hline Erythromycin & 10 & $\mathrm{R}$ & 11 \\
\hline Ampicillin & 25 & $\mathrm{R}$ & - \\
\hline
\end{tabular}


Jassim et al ./ Basrah J. Agric. Sci., 32(Spec. Issue 2): 75-84, 2019

Table (5): The value of resistance of Citrobacter freundii to antimicrobial agents.

\begin{tabular}{llll}
\hline Type of antibiotics & $\begin{array}{l}\text { Concentration } \\
(\mathrm{mcg} / \mathrm{g})\end{array}$ & $\begin{array}{l}\text { Type of } \\
\text { resistance }\end{array}$ & $\begin{array}{l}\text { Diameter of } \\
\text { inhibition zone } \\
(\mathrm{mm})\end{array}$ \\
\hline Nitrofurantoin & 300 & $\mathrm{R}$ & 10 \\
\hline Gentamicin & 10 & $\mathrm{R}$ & 8 \\
\hline Tetracycline & 30 & $\mathrm{R}$ & 12 \\
\hline Erythromycin & 10 & $\mathrm{R}$ & 10 \\
\hline Ampicillin & 25 & $\mathrm{R}$ & - \\
\hline
\end{tabular}

Table (6): The value of resistance of Vibrio cholerae to antimicrobial agents.

\begin{tabular}{lccc}
\hline Type of antibiotics & $\begin{array}{c}\text { Concentration } \\
\text { mcg.g }\end{array}$ & $\begin{array}{c}\text { Type of } \\
\text { resistance }\end{array}$ & $\begin{array}{c}\text { Diameter of } \\
\text { inhibition zone } \\
(\mathrm{mm})\end{array}$ \\
\hline Nitrofurantoin & 300 & $\mathrm{R}$ & ------ \\
\hline Gentamicin & 10 & $\mathrm{R}$ & 15 \\
\hline Tetracycline & 30 & $\mathrm{R}$ & 7 \\
\hline Erythromycin & 10 & $\mathrm{R}$ & 10 \\
\hline Ampicillin & 25 & $\mathrm{~S}$ & 23 \\
\hline
\end{tabular}

Table (7): The value of resistance of Serratia fonticola to antimicrobial agents.

\begin{tabular}{llll}
\hline Type of antibiotics & $\begin{array}{l}\text { Concentration } \\
\text { mcg.g }\end{array}$ & $\begin{array}{l}\text { Type of } \\
\text { resistance }\end{array}$ & $\begin{array}{l}\text { Diameter of } \\
\text { inhibition zone }(\mathrm{mm})\end{array}$ \\
\hline Nitrofurantoin & 300 & $\mathrm{R}$ & 16 \\
\hline Gentamicin & 10 & $\mathrm{~S}$ & 19 \\
\hline Tetracycline & 30 & $\mathrm{R}$ & \multicolumn{1}{c}{9} \\
\hline Erythromycin & 10 & $\mathrm{R}$ & 10 \\
\hline Ampicillin & 25 & $\mathrm{R}$ & ------ \\
\hline
\end{tabular}


Jassim et al ./ Basrah J. Agric. Sci., 32(Spec. Issue 2): 75-84, 2019

Table (8): Species identification of Aeromonas sobria isolates by the VITEK 2.

\begin{tabular}{|c|c|c|c|c|c|c|c|c|c|c|c|c|c|c|c|c|c|}
\hline 2 & APPA & + & 3 & $\mathrm{ADO}$ & - & 4 & PyrA & - & 5 & IARL & - & 7 & d CEL & + & 9 & BGAL & + \\
\hline 10 & $\mathrm{H} 2 \mathrm{~S}$ & - & 11 & BNAG & + & 12 & AGL Tp & + & 13 & $\mathrm{~d}$ GLU & + & 14 & GGT & $(+)$ & 15 & $\mathrm{OFF}$ & + \\
\hline 17 & BGLU & - & 18 & DMAL & + & 19 & dMAN & + & 20 & $\mathrm{dMNE}$ & + & 21 & BXYL & - & 22 & BAlap & - \\
\hline 23 & ProA & + & 26 & LIP & + & 27 & PLE & - & 29 & TyrA & + & 31 & URE & - & 32 & $\mathrm{dSOR}$ & - \\
\hline 33 & SAC & + & 34 & $\mathrm{~d}$ TAG & - & 35 & d TRE & + & 36 & $\mathrm{CiT}$ & + & 37 & MNT & - & 39 & $\mathrm{SKG}$ & - \\
\hline 40 & ILATK & - & 41 & AGLU & - & 42 & SUCT & + & 43 & NAGA & + & 44 & AGAL & + & 45 & PHOS & - \\
\hline 46 & GlyA & + & 47 & ODC & - & 48 & LDC & - & 53 & IHISa & - & 56 & CMT & + & 57 & BGUR & - \\
\hline 58 & 0129R & + & 59 & GGAA & + & 61 & IMLTa & - & 62 & ELLM & + & 64 & ILATa & - & & & - \\
\hline
\end{tabular}

Table (9): Species identification of Citrobacter freundii isolates by the VITEK 2.

\begin{tabular}{|c|c|c|c|c|c|c|c|c|c|c|c|c|c|c|c|c|c|}
\hline 2 & APPA & + & 3 & $\mathrm{ADO}$ & - & 4 & PyrA & + & 5 & IARL & - & 7 & d CEL & - & 9 & BGAL & + \\
\hline 10 & $\mathrm{H} 2 \mathrm{~S}$ & + & 11 & BNAG & + & 12 & AGL Tp & - & 13 & $\mathrm{~d}$ GLU & + & 14 & GGT & + & 15 & $\mathrm{OFF}$ & + \\
\hline 17 & BGLU & - & 18 & DMAL & + & 19 & dMAN & + & 20 & $\mathrm{dMNE}$ & + & 21 & BXYL & - & 22 & BAlap & - \\
\hline 23 & ProA & - & 26 & LIP & + & 27 & PLE & - & 29 & TyrA & + & 31 & URE & - & 32 & $\mathrm{dSOR}$ & + \\
\hline 33 & $\mathrm{SAC}$ & + & 34 & $\mathrm{~d}$ TAG & - & 35 & d TRE & + & 36 & $\mathrm{CiT}$ & + & 37 & MNT & - & 39 & $\mathrm{SKG}$ & + \\
\hline 40 & ILATK & - & 41 & AGLU & - & 42 & SUCT & + & 43 & NAGA & - & 44 & AGAL & + & 45 & PHOS & $(-)$ \\
\hline 46 & GlyA & + & 47 & $\mathrm{ODC}$ & - & 48 & LDC & - & 53 & IHISa & - & 56 & CMT & + & 57 & BGUR & - \\
\hline 58 & 0129R & + & 59 & GGAA & + & 61 & IMLTa & - & 62 & ELLM & + & 64 & ILATa & - & & & - \\
\hline
\end{tabular}


Table (10): Species identification of Vibrio cholerae isolates by the VITEK 2.

\begin{tabular}{ccccccccccccccccccc}
\hline 2 & APPA & - & 3 & ADO & - & 4 & PyrA & - & 5 & IARL & - & 7 & d CEL & - & 9 & BGAL & + \\
\hline 10 & H2S & - & 11 & BNAG & + & 12 & AGL Tp & - & 13 & d GLU & + & 14 & GGT & - & 15 & OFF & + \\
\hline 17 & BGLU & - & 18 & DMAL & + & 19 & dMAN & + & 20 & dMNE & + & 21 & BXYL & - & 22 & BAlap & - \\
\hline 23 & ProA & + & 26 & LIP & - & 27 & PLE & - & 29 & TyrA & + & 31 & URE & - & 32 & dSOR & - \\
\hline 33 & SAC & + & 34 & d TAG & - & 35 & d TRE & + & 36 & CiT & - & 37 & MNT & - & 39 & SKG & - \\
\hline 40 & ILATK & + & 41 & AGLU & - & 42 & SUCT & + & 43 & NAGA & - & 44 & AGAL & - & 45 & PHOS & - \\
\hline 46 & GlyA & - & 47 & ODC & - & 48 & LDC & - & 53 & IHISa & - & 56 & CMT & + & 57 & BGUR & - \\
\hline 58 & $0129 R$ & - & 59 & GGAA & + & 61 & IMLTa & - & 62 & ELLM & + & 64 & ILATa & - & & & - \\
\hline
\end{tabular}

Table (11): Species identification of Serratia fonticola isolates by the VITEK 2.

\begin{tabular}{cccccccccccccccccccc}
\hline 2 & APPA & - & 3 & ADO & + & 4 & PyrA & - & 5 & IARL & + & 7 & d CEL & + & 9 & BGAL & + \\
\hline 10 & H2S & + & 11 & BNAG & + & 12 & AGL Tp & - & 13 & d GLU & + & 14 & GGT & - & 15 & OFF & + \\
\hline 17 & BGLU & + & 18 & DMAL & + & 19 & dMAN & + & 20 & dMNE & + & 21 & BXYL & - & 22 & BAlap & - \\
\hline 23 & ProA & + & 26 & LIP & + & 27 & PLE & + & 29 & TyrA & + & 31 & URE & - & 32 & dSOR & - \\
\hline 33 & SAC & + & 34 & d TAG & + & 35 & d TRE & + & 36 & CiT & - & 37 & MNT & - & 39 & SKG & - \\
\hline 40 & ILATK & - & 41 & AGLU & - & 42 & SUCT & - & 43 & NAGA & - & 44 & AGAL & - & 45 & PHOS & - \\
\hline 46 & GlyA & - & 47 & ODC & + & 48 & LDC & - & 53 & IHISa & - & 56 & CMT & + & 57 & BGUR & - \\
\hline 58 & $0129 R$ & - & 59 & GGAA & - & 61 & IMLTa & - & 62 & ELLM & + & 64 & ILATa & - & & & - \\
\hline
\end{tabular}




\section{Discussion}

The semi-enclosed aquaculture system in Basrah province has been used as an alternative to the closed systems due to the lack of sufficient experience for farmers to manage with the closed systems, which can avoid wastes problem, increase ammonia and decrease the dissolved oxygen content. The health problems in farms that rely on closed and semi-closed systems were recorded in 10 farms with a total area of $1233.2 \mathrm{~m}^{2}$ with different deaths (Jassim, 2019). This study is the first attempt to identify the most important health problems facing this type of culture. The bacterial infections recorded during the study (bacterial gill disease, skin ulcer disease and intestinal inflammation disease) are due to the poor health management that contributed to the infection. The fishes were transported in improper ways and with high densities. Farmers also significantly reduce water level in the ponds weekly for the purpose of cleaning the tank which was originally designed in a way that does not ensure the disposal of fish wastes, which caused stress and decrease immunity contributed to the incidence of such diseases.

Bacterial gill disease and skin ulcer disease recorded in Shatt Al-Arab and Abu AlKhaseeb farms are due to of above conditions and also due to the use of corrupted floating feed stored in high moisture conditions which, in turn, was the main reason to the infection of fishes with inflammatory of intestine in Abu Al-Khaseeb farms.

A. sobria (38.46\%) was the predominant species (Table 2) being isolated from skin of fishes in both districts while it was found in gill of fishes in AbuAl-Khaseeb farms (Table 2). Many studies recorded this bacterium from different organs of various fish species and the infection was related with changes in water quality. A. sobria was isolated from the liver, kidneys, spleen and skin lesions of farmed perch fish (Wahli et al., 2005). Also, it was recognized from C. carpio by Kozińska et al. (2002), Garra rufa by Majtán et al. (2012) and Labeo rohita by Dar et al. (2016). Barzani \& Mustafa (2016) recognized $A$. sobria in intestine of fishes and water of aquarium in Erbil province, Iraq. AlHisnawi (2016) identified this bacterium from Liopropoma santi and water of a local river in Kerbala city, Iraq.

The second species of bacteria, C. freundii was isolated from the gills and intestine. Because of $C$. freundii isolated from different species of fishes and caused health problems in intestine, gills and skin of fishes so, recorded it living in bad water quality was expect as in this study. Al-Obaidi \& AlDabbagh (2012) isolated it from intestine of C. carpio which collected from Tigris river passing through Mosul city, Iraq. Abid \& AlHamdani (2016) recorded this species as one of the causative agents of ulcerated skin lesion of $C$. carpio which cultured in Sulaimani province, Iraq. Al-Hisnawi (2016) identified it in the intestinal mucosa and gills of L. santi from a local river in Kerbala city, Iraq. Hammood \& Ibrahim (2018) identified this bacterium in gut of Alburnus mossulensis, C. carpio and Garra elegans from Tigris river in Baghdad city.

$V$. cholerae $(21.53 \%)$ was isolated from the gills and considered as pathogen of fishes. Identification of this species in the two districts in the same organ refers to its importance as an infectious agent. This species was recorded either with A. sobria or with C. freundii. Al-Taee et al. (2017) recorded six species of Vibrio which included 
$V$. cholerae in farmed common carps from different districts of Basrah city. Al-Hussainy et al. (2017) isolated this bacterium from frozen and fresh fishes which were collected from fish market of Basrah city and Thi Qar province. Hammood \& Ibrahim (2018) identified this species in gut of A. marmid and G. elegans.

S. fonticola (10.76\%) was isolated from intestine of fishes in Abu Al-Khaseeb district. This bacterium has a wide distribution in aquatic environments and also regarded as a significant human pathogen (Carneiro et al., 2013). Reporting this species as pathogen for fishes was scarce. Ture et al. (2018) recorded this bacterium as pathogen of whiting (Merlangius merlanguseuxinus) in the Eastern Black Sea coast of Turkey. Recording of this bacterium is considered here as the second record as pathogen of fishes in Iraq after that of Majeed et al. (2016).

A. soberia was sensitive for Nitrofurantoin and this result is in agreement with Barzani \& Mustafa (2016). C. freundii was resistance for all antibiotic. S. fonticola was sensitive to Gentamicin. Results of the present study about the sensitivity of above species are in agreement with Al-Obaidi \& Al-Dabagh (2012) and Stock et al. (2003). V. cholerae was sensitive for Ampicillin while many studies mentioned this species as resistance for this antibiotic. However, some studies reported it as a sensitive such as of Ali et al. (2019). It is important to mention that treatment of diseased fishes which recorded in this study by using oxytetracycline was excellent and the healing achieved $100 \%$.

\section{Conclusions}

Three types of diseases were recorded in semi-enclosed fish culture systems and four species of bacteria were identified. The results of this study confirm that the emergence of diseases is caused by mismanagement and that these diseases undoubtedly will appear in other farms due to lack of experience among farmers.

\section{Acknowledgements}

We would like to thank Dr. Eman A. AlImarah from Marine Science Centre, University of Basrah for her valuable review. Also, we would like to thank the authorities of the Marine Science Centre for supporting this study.

\section{References}

Abid, O.I. \& Al-Hamdani, A.H. (2016). Study of the causative agents of ulcerated skin lesions of carp fish ponds at Sulaimani province. Basrah J. Vet. Res., 15(3): 1-19.

Al- Hussainy K.S.; Al-Tememy M. \& AlGboory A. (2017). Effect of some environmental condition Vibrio cholera and Vibrio fluvialis bacteria isolating from fish proffered in local markets of Basrah and Nasiriyah city. Diyala J. Agric. Sci. 9(2): 1-15.

Al-Hisnawi, A.A.; Mustafa, J.M.; Yasser, Y.K.; Hussain, K.A. \& Jabur, A.M. (2016). Influence of aquatic environment on microbiota of Liopropoma santi fish in a local river in Iraq Karbala Int. J. Mod. Sci., 2(1): 41-45.

Ali, G.N.; Aboyadak, I.M. \& Gouda, M.Y. (2019). Rapid detection and control of Gram-negative bacterial pathogens isolated from summer mortality outbreak affecting tilapia farms. J. Biol. Sci., 19(1): 24-33.

Al-Obaidi, N.; A.K. \& Al-Dabbagh, S.Y.A. (2012). Isolation and diagnosis of pathogenic bacteria from intestines of Cyprinus carpio from Tigris River in 
Mosul city. J. Educ. Sci., 25(3): 25-36. (In Arabic).

Al-Taee, A.M.R.; Khamees, N.R. \& Al Shammari, N.A.H. (2017). Vibrio species isolated from farmed fish in Basra city in Iraq. J. Aquac. Res. Dev., 8(2): 472. DOI: 10.4172/2155-9546.1000472.

Barzani, K.K.M. \& Mustafa, A.K. (2016). Bacteriological and molecular study of Aeromonas sobria isolated from different sources in Erbil Province. ZANCO J. Pure Appl. Sci., 27(6): 11-18.

Bregnballe, J. (2015). A guide to recirculation aquaculture: An introduction to the new environmentally friendly and highly productive closed fish farming systems. FAO \& Eurofish Int. Organ. www.fao.org/publications.

Buller, N.B. (2004). Bacteria from fish and other aquatic animals: A practical identification manual, $2^{\text {nd }}$ ed. CABI Publ. Ser., Wallingford: 919pp.

Carneiro, A.R.; Ramos, R.T.J.; Baraúna, R.A.; de Sá, P.H.; Almeida, D.M.; Barbosa, S.; Pereira, A.; Alves, A.; Egas, C.; Correia, A.; Henriques, I. \& Silva, A. (2013). Draft genome sequence of Serratia fonticola LMG7882T isolated from freshwater. Genome Announc., 1(6): e00971-13. Doi: 10.1128/genomeA.0097113.

CLSI. Clinical and Laboratory Standards Institute. (2016). Performance Standards for Antimicrobial Susceptibility Testing; $26^{\text {th }}$ ed. CLSI Supplement. M 100-S. Wayne, PA: 251pp.

Dar, G.H.; Kamili, A.N.; Chishti, M.Z.; Dar, S.A.; Tantry, T.A. \& Ahmad, F. (2016). Characterization of Aeromonas sobria isolated from fish Rohu (Labeo rohita) collected from polluted pond. J. Bacteriol.
Parasitol., 7(3): 1-4. doi:10.4172/21559597.1000273.

Hammood, N.W. \& Ibrahim, I.A.J. (2018). Bacterial content in gut for different species of fish collecting from Tigris river in Baghdad city, Iraq. Tikrit J. Pure Sci., 23(3): 33-37.

Jassim, A.A.R. (2019). Cultured fish diseases in Basrah province for the years 2014, 2015 and 2016. Iraqi J. Aquacult. In Press (In Arabic).

Kozińska, A.; Figueras, M.J.; Chacon, M.R. \& Soler, L. (2002). Phenotypic characteristics and pathogenicity of Aeromonas genomospecies isolated from common carp (Cyprinus carpio L.). J. Appl. Microbiol., 93(6): 1034-1041.

Majeed, K.R.; Jaayid, T.A. \& Al-Khayoon, S.N.A. (2016). Isolation and identification of Enterobacteriaceae and detection it's for producing histamine from the fish Scomberoides commersonianus, Chirocentrus dorab, Megalaspis cordyla and Tenualosa ilisha. Thi-Qar Univ. J. Agric. Res., 5(1): 47-68. (In Arabic).

Majtán, J.; Černy, J.; Ofúkaná, A.; Takáč, P. \& Kozánek, M. (2012). Mortality of therapeutic fish Garra rufa caused by Aeromonas sobria. Asian Pac. J. Trop. Biomed., 2(2): 85-87.

Qi, W. (2002). Social and economic impacts of aquatic animal health problems on aquaculture in China. In: Arthur, J.R.; Phillips, M.J.; Subasinghe, R.P.; Reantaso, M.B. \& MacRae, I.H. (Eds.). Primary aquatic animal health care in rural, smallscale, aquaculture development. FAO, Fish. Tech. Pap. No. 406: 55-61.

Stock, I.; Burak, S.; Sherwood, K.J.; Gruger, T. \& Wiedemann, B. (2003). Natural antimicrobial susceptibilities of strains of 
'unusual' Serratia species: S. ficaria, $S$. fonticola, S. odorifera, S. plymuthica and $S$. rubidaea. J. Antimicrob. Chemother., 51(4): 865-885.

Ture, M.; Misir, S.; Altuntas, C. \& Kutlu, I. (2018). A survey of some bacterial fish pathogens on whiting (Merlangius merlangus euxinus) in eastern Black Sea coast, Turkey. Turk. J. Fish. Aquat. Sci., 18: 1325-1329. http://doi.org/10.4194/1303-2712v18_11_09.

Wahli, T.; Burr, S.E.; Pugovkin, D.; Mueller, O. \& Frey, J. (2005). Aeromonas sobria, a causative agent of disease in farmed perch, Perca fluviatilis L. J. Fish Dis., 28(3): 141150. 